\title{
Governmentalities without policy capacity
}

\author{
Gloria Regonini ${ }^{1}$
}

Published online: 11 February 2017

(C) The Author(s) 2017. This article is published with open access at Springerlink.com

\begin{abstract}
The professional community of policy experts takes it for granted that all governments seek to strengthen their policy capacity, considering it a key indicator and requisite of their success. Yet this assumption is far from universal, even in some European Union countries with long and complex institutional histories. If we look at the informed and explicit use of policy analysis tools in France, Germany, Spain, and Italy, we have to conclude that this paradigm is not completely integrated into their governmentality. In these countries, three disciplinary approaches warrant especial attention as generators of competencies recognized as usable knowledge for public decisions: 'law,' 'public finance' and 'public administration.' Where the standard operating procedures of democratic institutions appear to be fully defined on the basis of these three categories, the inclusion of the policy perspective encounters major difficulties. In these contexts, the most important obstacle is the fear that the new paradigm will threaten the balance among the constitutional bodies, especially to the detriment of the legislature, and that it will constrict the political leadership. This explains why some countries, such as France and, most recently, Italy, have attempted to resolve the impasse by resorting to the strongest of legitimations: inclusion in their constitutions of public policy evaluation as a function of Parliament. This choice is certainly important, but in itself it does not guarantee recognition of the policy paradigm as a science for democratic institutions.
\end{abstract}

Keywords Policy analytical capacity · Governmentality · Parliamentary oversight . Democracy

Gloria Regonini

gloria.regonini@unimi.it

1 Dipartimento di Scienze Sociali e Politiche, Facolta' di Scienze Politiche, Economiche e Sociali, Universita' degli Studi di Milano, Via Conservatorio 7, 20122 Milan, Italy 


\section{Introduction}

Thirty years ago, Brian Hogwood, one of the authors who has contributed most to the spread of policy analysis in Europe, wrote: 'Often American authors write as though the United States were the only place in the universe which had public policy' (Hogwood 1984: 27). Today, many authors, in universities or international organizations, write as though the entire universe had public policy. This assumption is generally taken for granted in international comparisons, both descriptive and evaluative, especially when they concern countries with consolidated democracies.

In fact, the capacity of governments to effectively formulate, implement and evaluate their public policies is part of the better known and more standardized indicators of 'good governance. ${ }^{11}$ In these comparisons, it is taken for granted that the activities through which governments seek to change (or maintain) the status quo can be universally defined as 'policy making.'

This assumption is fully consistent with Thomas Dye's well-known definition: 'Public policy is whatever governments choose to do or not to do' (Dye 1972: 1). This indeterminate definition has the advantage of allowing the inclusion of all countries in the comparison, even when the self-representations provided by their institutions make no reference to the categories of policy analysis and evaluation and describe the activities of their governments in terms of value affirming, reassignment of rights and duties, or conflict resolution.

From this perspective, public policies are the output of governments like radon emissions are the output of granite rocks. The correct evaluation of their strength is guaranteed by the competence of the observers, and their capacity to develop measurement methods based on objective standards.

But, as explained in lesson number one of every course in public policy, Dye's definition is the most inclusive extreme of a continuum at whose opposite end is a much more demanding and restrictive concept. Since the founder of policy sciences, Harold Lasswell (1951), numerous authors have associated policy making with a conscious activity of social problem solving: '[Policy is] a purposive course of action followed by an actor or set of actors in dealing with a problem or matter of concern' (Anderson 1975: 3). In fact, all the most widely used models of analysis are based on definitions of the policy cycle whose stages have close relationships with those of problem solving in complex adaptive social systems, from problem definition, through formulation of alternative solutions, to implementation and evaluation (Peters 1996; Lodge and Wegrich 2014).

In international comparisons, this second, more restrictive, definition of policy comes into play when the quality of what governments do is assessed. The explicit and intentional utilization of these tools in institutional contexts by decision-makers indicates, in fact, a set of abilities central to the requirements of good governance, usually denoted with expressions such as 'policy capacity,' 'policy management,' 'policy efficacy,' and 'evaluation capacity' (De Peuter and Pattyn 2009).

The concept of policy analytical capacity (CAP) has the merit of giving greater clarity to these specific technical skills by showing the differences that they make when applied intelligently and appropriately from the first stage of decision-making onwards, and not just in the phase of ex post evaluation (Howlett 2009; Woo et al. 2015).

\footnotetext{
${ }^{1}$ See, for instance, World Bank, The Worldwide Governance Indicators (WGI), http://info.worldbank.org/ governance/wgi/index.aspx\#home.

World Economic Forum, The Global Competitiveness Index (GCI) http://www3.weforum.org/docs/ GCR2014-15/GCR_Chapter1.1_2014-15.pdf.
} 
From a descriptive point of view, this type of assessment has great informative potential because it enables comparison among countries with very different political institutions and administrative structures. Its shortcomings are usually emphasized by those who consider these criteria to be particularly problematic when applied to developing countries, where these analytical abilities are harder to find, with a consequent overestimation of the capacity gaps of those governments. Indeed, in this frame, the fact that some governments do not define their activities in a manner such that they can be related to the categories of policy analysis does not exempt them from this assessment; rather, it gives rise to a negative evaluation, being interpreted as an outright deficiency, a shortage in their steering capabilities.

This paper seeks to explain why, for very different reasons, these parameters may be inappropriate even for some major continental European countries, such as France, Germany, Spain, and Italy, with long and complex institutional histories, and where the concept of policy as a logic of action to solve problems of collective importance is not yet fully part of the tools of government.

Until the end of the 1980s, the governments of these countries accomplished important changes, such as post-war reconstruction, the social reforms of the $1960 \mathrm{~s}$, the creation of new infrastructures, and the reorganization of health services, although they entirely ignored the instruments that derive from the more exacting concepts of policy. The preparatory phase was not structured on the basis of the recommendations for smart policy formulation. The implementation phase ignored the categories of what terms itself 'the logic model' (Bickman 1987; Kellogg Foundation 2004). The ex post assessment phase was based on evidence that an analyst would regard as entirely insubstantial. Some of these interventions were successful, and others were not. On considering the various international comparisons, it is evident that France and Germany achieved positive results in many sectors. Other countries, such as Italy, registered severe failures. But it is difficult to tie the success of these demanding interventions to the use of categories that, until a few years ago in those countries, existed only in university textbooks and are still today unrelated in many sectors to the logic actually followed by those who take public decisions and those who implement them.

The first goal of our investigation is to gain better understanding of the institutional and epistemic balances relied upon by these European systems of government whose consolidated repertoires of standard operating procedures do not comprise the prescriptions that derive from the most exacting concept of policy. The second objective is to analyze the problems of compatibility which arise in the same countries when, especially under the pressure of external dynamics, they attempt to adopt this unprecedented view of public intervention. These difficulties tend to be neglected in comparisons that consider the lack of policy capacity as merely a gap to be filled with a 'software update' to enlarge the functionalities of government. Instead, we contend that, in many respects, in these countries the competencies prescribed equate to the installation of a new operating system. This explains why, in some countries, the adoption of this analytical perspective requires the formally more stringent legitimacy provided by the inclusion of policy evaluation in constitutional texts, a process which France has already completed, and which Italy has recently undertaken, but without success.

To prove this thesis, we will use the concept of governmentality (Foucault 1977-1978) to identify the epistemic, institutional and regulatory aspects that differentiate the logic of public choice in the Anglo-American countries, which have incorporated the use of policy tools because of endogenous pressures and in incremental manner, from the continental European countries, where this assimilation has exogenous origins and a greater impact. 
In particular, we will explore the critical function of evaluation policy in parliaments; an aspect that sheds light on the relationship between, on the one hand, the mechanisms of representative democracy based on political preferences, and on the other, the technical competences aimed at improving the treatment of problems of collective importance (Regonini 2012).

\section{From governance to governmentality}

In order to understand the causes of the differing levels of policy capacity among democratic countries, useful analytical insights may arise if one uses the concept of governmentality rather than that of governance (Burchell et al. 1991; Miller and Rose 2008; Bevir 2010). 'Governmentality' is a term coined by Foucault-and which he declined with a variety of meanings - in a complex endeavor to reconstruct the changes that between the second half of the 1500s and the early 1800s laid the bases for the exercise of the particular type of power which has since then distinguished the mode of government in the modern European states: 'The modern state is born, I think, when governmentality became a calculated and reflected practice' (Foucault 1977-1978: 222). One of these meanings brings to the fore the relationship between, on the one hand, political institutions, their organizations and practices, and on the other, the conceptions of the public sphere that legitimate and support them by providing competencies, technical procedures, and ethical justifications. The growth of integration between the state organization and the "sciences of the public institutions'-i.e., epistemic perspectives that give a both 'ontological' ${ }^{2}$ and technical foundation to the competencies attributed to themselves by the political authorities - has played a crucial role in consolidation of the modern idea of government (Foucault 1977-1978: 144).

The second interesting aspect of the concept of governmentality is the nondeterministic manner in which reconstruction is made of the appearance or disappearance of the various categories able to render the public sphere intelligible, organizable and modifiable (Rose 1996; Bevir 2010). The beginning and outcome of this process are identified thus by Foucault: 'the state of justice of the Middle Ages became the administrative state in the fifteenth and sixteenth centuries and was gradually "governmentalized" (Foucault 19771978: 144). Yet the way in which this process came about in different countries is very distant from a pattern of uniform development. It is precisely the genealogy of the concept of policy that furnishes a clear example of the nonlinearity of the trajectories whereby, in different periods and in different nations, the categories used to define what governments can and must do have arisen. As not only Foucault but also many European political scientists (Heidenheimer 1986; Bobbio 1987; Sartori 1989) have emphasized, in the second half of the 1700s, the feature shared by the English word 'policy' (or 'police'), the German 'polizei,' and the French 'police' was still reference to government activity as a service to the 'politeia' - as the pursuit of the well-being and happiness of the governed (Heidenheimer 1986: 10). ${ }^{3}$ It was with this meaning that the terms were employed by Friedrich Hegel and Adam Smith. In the German-speaking countries, Polizeiwissenschaften were

\footnotetext{
${ }^{2}$ Here the word 'ontology' is used with reference to one of the most quoted definitions in the Knowledge Engineering community: 'An ontology is an explicit specification of a conceptualization' (Gruber 1993: 199).

${ }^{3}$ Heidenheimer points out that 'The Prince was published as Machiavelli's Policei in the German translation'.
} 
studied for purposes very similar to those of the contemporary policy sciences (Dean 1994: 185).

During the 1800s, in the countries of continental Europe, the terms 'police,' 'polizei,' 'polizia,' 'policía' increasingly acquired their contemporary meaning as apparatuses for the control and repression of deviant behavior (Dyson 1980), leaving France, Germany, Italy, and Spain without an equivalent for the English word 'policy.' There is one date that above all marks the extent of this divergence: namely 1943. In that year, Harold Lasswell later acknowledged as the father of policy sciences, while serving as Chief of the Experimental Division for the Study of War Time Communications at the Library of Congress, coauthored with Myres McDougal the article entitled 'Legal Education and Public Policy: Professional Training in the Public Interest' (Lasswell and McDougal 1943). But in that same year, Europe was devastated by the most atrocious Polizei-Staat experiment of all human history.

Even after the consolidation of democratic regimes in all the countries of continental Western Europe, the everyday languages of Germany, France, Italy, and Spain still possess a single term to denote the entire 'family-polis of words' that in English is articulated among 'polity,' 'politics,' and 'policy' (Heidenheimer 1986: 4; von Beyme 2013). In those countries, and not only in France, policy analysis and evaluation remain 'a "pure" import' (Muller 2008: 53).

Detailed reconstruction of the problems encountered by the institutionalization of policy analysis in Germany (Blum and Schubert 2013) and France (Jobert and Muller 1987; Mény and Thœnig 1989; Giraud and Warin 2008) yields a composite picture of the factors which impede this implant. As we have seen, comparisons which employ standard definitions of governance represent the weak policy capacity of some governments as a deficit, a lack, a void. An approach centered on governmentality can evidence that the under-utilization of policy analysis and evaluation is due to the success of other disciplinary perspectives in acquiring legitimacy and robustness as sciences of institutions that furnish clear and convincing representations of what is meant when one speaks of 'government.' As we shall shortly see, the reference is mainly to three ontologies-'law,' 'public finance,' and 'public administration'-which in many continental European countries continue to provide the semantic frames of reference for designing and giving account of what institutions do.

Finally, the idea of governmentality acknowledges that ' $[\mathrm{t}]$ here is no power relation without the correlative constitution of a field of knowledge, nor any knowledge that does not presuppose and constitute at the same time, power relations' (Foucault 1977-1978: 27). In our democratic societies, compatibility between power relations and fields of knowledge requires firstly that any new interpretation of what the institutions do must not weaken the capacity for control that citizens, voters and taxpayers are entitled to exercise over governments through their representatives, and secondly that it is not contrary to the division of powers among the legislature, executive, and judiciary. As we shall see in what follows, where policy analysis and evaluation remain 'pure' imports, if not external impositions, these guarantees are often considered under pressure.

\section{The other disciplines of the public institutions}

The first problem that the policy paradigm must overcome when it leaves the domain of academic study and proposes itself as a tool with which to define and improve what governments do is to withstand comparison with the disciplinary perspectives that already enjoy solid institutionalization in the guidance of res publica. In the countries of 
continental Europe, three areas are universally recognized as essential components of not good governance (a term incomprehensible for ordinary citizens and their representatives in these countries), but good government: clear laws, carefully handled public money, and well-organized administrations. The labels for these three areas-law, public finance, and public administration-share an ambivalence: They denote both the levers for government action and the disciplines furnishing the parameters with which to formulate, evaluate, and improve decisions in their respective fields of reference. This intimate relationship between power and knowledge, between the production of effects that change the lives of citizens and the development of competence testifies to the close integration among these three components in the governmentality of contemporary states.

As regards the 'law' paradigm, its institutional embeddedness is quite clear, given that the 'rule of law' has become synonymous with respect for the rights of citizens, from the rise of the medieval 'state of justice' to modern liberal constitutionalism (Foucault 1977-1978).

The institutional recognition of the 'public finance' paradigm has its roots in the modern revolutions whose purpose was to curb the sovereign's power to tax and to spend (Webber and Wildavsky 1986). In order to ensure the proper management of public money, the competencies of parliaments were extended and specific independent structures, the Supreme Audit Institutions (SAI), were created.

As regards the public administration, in continental Europe, at least in theory, and at least until very recent years, the principles of 'precision, speed, unambiguity, knowledge of the files, continuity, discretion, unity, strict subordination, reduction of friction and of material and personal costs' (Weber 1922-1978: 971) exercised within the constraints of the Napoleonic administrative codes or the Rechtsstaat principles, were considered to protect, and not to threaten, the constitutional rights of citizens.

These three building blocks are powerful descriptors that provide comprehensive and consistent accounts of what governments do. And they are also authoritative prescriptive frames that indicate how governments should do what they do. Each of them has its own production cycle, parameters to measure performance, and formal rules to ensure its procedural accountability and compatibility with the powers of the constitutional bodies. Moreover, a set of mechanisms linking and integrating the three perspectives - for instance, rules on the financial coverage of laws and the competencies of administrative justice-ensure unity and coherence among the different logics.

The concrete outcomes of this type of 'policyless' governmentality differ greatly among countries. In all international comparisons, Italy is invariably ranked as less efficient than France and Germany and often contends for last place with Spain and Portugal. And yet for experts, for common sense, and for politicians themselves, it is within these three 'ontologies' that solutions for the government inefficiencies should be found: simpler and more focused laws, without endless cross-references and long sequences of subordinate legislation; public expenditures without corruption, waste and clientelism; criteria for the organization of public administrations more concerned to reward the merit of officials and to respect the needs of citizens and businesses.

\section{Obstacles to institutional recognition}

Where the mission of democratic institutions appears to be fully defined on the basis of these three categories, the inclusion of the policy perspective encounters major obstacles. As we saw in the first section, as long as the policy approach is understood as a generic 
exercise in aggregation and discussion of facts and opinions on specific topics, its accommodation with the functioning of the institutions and the state's powers does not raise problems. The tensions arise when the policy paradigm requires the activation of specific competencies different from those already recognized as 'sciences of institutions' for two reasons. First, policy analysis and evaluation refers not to generic problem-dealing practices -in this general sense, also a tribe that performs animal sacrifices to obtain rainfall is a policy-making institution-but to specific strategies of logical reasoning, with their phases and techniques of verification, albeit adapted to the complexity of situations. Secondly, this paradigm claims that it is able to integrate the other analytical perspectives to furnish more meaningful criteria for action and assessment: not only well-written laws, but solutions that can be evaluated for their impact; not only balanced budgets, but value for money; not only administrative efficiency, but results.

Incorporating these claims into the functioning of democratic institutions encounters four obstacles. The first has to do with the flexibility and antiformalism of the categories used by policy analysis and evaluation. The key strength of the second-generation policy paradigm, in fact, consists in its ability to take account of the limits to human rationality, as does the post-Simon problem-solving logic on which it draws: 'These limits are imposed by the complexity of the world in which we live, the incompleteness and inadequacy of human knowledge, the inconsistencies of individual preference and belief, the conflicts of value among people and groups of people, and the inadequacy of the computations we can carry out, even with the aid of the most powerful computers' (National Academy of Sciences 1986: 20). But in the continental European countries to which we refer, the multiple adaptable approaches typical of policy analysis and evaluation become obstacles to its institutional use because their potential indeterminacy can threaten the separation of powers and the rights of citizens to hold the governments to account. In these countries, there is widespread understanding of what law enforcement is, who should ensure it, and who should resolve any ambiguities in it. Likewise, it is quite clear what constitutes public spending without budget coverage and what responsibilities it entails. But what policy implementation is, on whom its success depends, what consequences they should suffer in the event of failure, and who should establish it are much more complex issues (Bovens 1998; Pierre and Peters 2005). As noted by von Beyme (2013) with reference to the democracies of continental Europe, it is precisely the countries with a strong and cumbersome statehood that find it most difficult to incorporate the policy paradigm into their governmentality.

The second obstacle overlaps also geographically with the first. It consists in linguistic incompatibility, given that large part of the lexicon of policy sciences does not have (or has lost) equivalents in the neo-Latin and German languages. While this is not a problem for specialists, ${ }^{4}$ a science of and for institutions incomprehensible to the general public is a contradiction that makes 'unusable' the knowledge produced within this paradigm to improve the quality of public decisions.

From the point of view of its institutional acknowledgment, the nonintuitive meaning of 'policy' has impeded the processes of incremental assimilation that in Britain and the USA have allowed the gradual insertion of policy skills into the technical structures at the service of the executive and the legislature. Consider, for example, the increase in the

\footnotetext{
${ }^{4}$ But also the experts sometimes have problems: In a call for applications of the European Personnel Selection Office in February 2009 at http://europa.eu/epso/discover/job_profiles/index_en.htm, a post which in English was 'Policy Officer,' on the corresponding Italian page was termed 'Funzionario' (a generic public official) and on the French one 'Chargé de mission.'
} 
number of policy analysis experts in the Congressional Research Service of the Library of Congress in the USA and the Research Service of the Commons Library in the UK: This process has been simply considered a response to the need to update the knowledge available to lawmakers.

This observation introduces the third obstacle encountered by institutionalization of the policy paradigm: competition with more consolidated and accredited epistemic communities - those of lawyers, experts in public finance and public management. Competences are expertise, but they are also domains, jurisdictions, authorities (Foucault 1977-1978; Abbott 1988). The disciplines recognized as indispensable for the functioning of constitutional bodies, and the administrative machinery ensures ample benefits for their specialists in terms of both stable careers and appointments to public bodies or advisory committees. Also available to these specialists are a series of side-activities in schools of public administration, consultancy companies, think tanks, and the media. It should be pointed out, however, that investigation of this issue should consider not only the strength of the paradigms recognized as sciences of institutions but also the weakness of the challengers. In fact, compared with the corresponding Anglo-American organizations, the continental epistemic communities aggregated around the social and behavioral sciences have in recent decades shown scant interest in research applied to the problems addressed by the political institutions and the social relevance of their studies. It is therefore understandable that they have been repaid in kind.

\section{Compatibility with the democratic game}

We come now to the fourth and most important obstacle to the inclusion of policy analysis and evaluation among disciplines with institutional dignity: its close proximity to politics; a proximity which tends to become an overlap in the continental countries, which, as we have seen, have only one term for the entire 'polis-family of words.' Those who warn of the dangers of embedding the policy paradigm in the public sphere often express fear that this will lead to a democratic deficit.

In order to analyze the diverse components of this argument, it is useful to go back a hundred years to another great change in contemporary governmentality, when it was the embedding of the 'public administration' ontology that was seen as a threat to the constitutional democracy in Europe and in the USA.

The elements among which to fit the last piece of the puzzle are the same today as they were a hundred years ago, and they can be grouped into two broad categories. The first problem is where to place the new competencies and their providers in the constitutional scheme (Rosenbloom 1987), which in democratic societies is based on a delicate balance among the legislature, executive, and judiciary. Rosenbloom uses the term 'retrofitting' to define the search for an arrangement able to embed this new reality within the institutions wanted by the Founding Fathers: "One of the "big questions" of American public administration has been how to retrofit, or integrate, the federal administrative state into the nation's constitutional scheme' (Rosenbloom 2000: 39).

The second problem is how to extract value from the new ontology and how to apply it for the common good without restricting the space for politics, competition for consensus, and the strength of leadership produced by this mechanism (Goldwin 1980).

Even in the country that has made the greatest contribution to establishing the policy sciences as building blocks of contemporary governmentality, these two issues are not fully 
resolved, and they have reemerged even in recent times (Schambra 2009) in terms that specifically link the risks of this retrofitting with those of the administrative reforms of the Progressive Era:

Policy science, in this perspective, appears as one in a long series of efforts by the Progressive Movement and its heirs to change the character of the American political system - to transfer power from the corrupt, the ignorant, and the self-serving to the virtuous, the educated, and the public-spirited, and to enhance the capacity of the executive to make and carry out internally-consistent, comprehensive plans for implementing the public interest (Banfield 1977: 7).

According to this perspective, the power of policy czars and policy wonks-which is the power of agenda setting in the policy design phase, and the power of evaluation in the postimplementation one - threatens the balance among the constitutional bodies, especially to the detriment of the legislature, and it humiliates politics, which does not consist of scientific evidence, but rather, according to Madison (1787), of 'opinions, passions and interests. ${ }^{5}$

If we go back to more than a hundred years ago, to the phase of the institutional rooting of government as we know it today, we can find similar concerns in two great scholars: Woodrow Wilson in the USA and Max Weber in Germany, who, although they analyzed very different contexts, used similar terms to identify potential fault lines in the democratic balance and proposed similar solutions. Both, in fact, saw strengthening of the legislature's function of oversight as the main instrument both to upgrade the role that constitutions assign to the parliament and to improve the quality of the political game. For both, the function of lawmaking, from which the legislature takes its name, should be combined with the exercise of close control over the administration.

Wilson wrote:

It is the proper duty of a representative body to look diligently into every affair of government and to talk much about what it sees. It is meant to be the eyes and the voice, and to embody the wisdom and will of its constituents. (...) The informing function of Congress should be preferred even to its legislative function. The argument is not only that discussed and interrogated administration is the only pure and efficient administration, but, more than that, that the only really self-governing people is that people which discusses and interrogates its administration. (Wilson 1885: 303).

\section{Weber argued likewise:}

There is no substitute-for the systematic cross-examination (under oath) of experts before a parliamentary commission in the presence of the respective departmental officials. This alone guarantees public supervision and a thorough inquiry. Today, the Reichstag simply lacks the right to proceed in this fashion: the constitution condemns it to amateurish ignorance (Weber 1918: 1418).

Both authors saw this assumption of responsibility as essential for the upgrading of politics.

Wilson wrote:

The talk on the part of Congress which we sometimes justly condemn is the profitless squabble of words over frivolous bills or selfish party issues. It would be hard to

\footnotetext{
5 According to Napoleon, 'Power is based upon opinion. What is a government not supported by opinion? Nothing.' (cit. from Ellul 1965).
} 
conceive of there being too much talk about the practical concerns and processes of government. Such talk it is which, when earnestly and purposefully conducted, clears the public mind and shapes the demands of public opinion. (Wilson 1885: 304).

Weber, who was closely attentive to the relationship between the quality of political leadership and the functions of the parliament, which he considered to be 'a recruiting ground,' 'a palaestra' for leaders, wrote:

...For only a working, not a merely speech-making parliament can provide the ground for the growth and selective ascent of genuine leaders, not merely demagogic talents. A working parliament, however, is one which supervises the administration by continuously sharing its work. (Weber 1918: 1416).

\section{The parliamentarization of the policy paradigm}

Hence, an effective oversight function by parliaments is regarded as a necessary requirement for an expansion of administrative capacities to be assimilated into the constitutional framework. This third function, which integrates the powers of legislatures to make laws and to tax and spend into a new pattern, developed in the Anglo-American models by assigning new tasks to the Comptroller Generals (or Comptroller and Auditor-Generals), which already acted as parliamentary watchdogs in monitoring the executive's expenditure.

In the continental European democracies, parliamentary oversight has not been able to rely on watchdogs whose only principal is the legislature, because their constitutions assign the role of Supreme Audit Institutions to independent structures which report to both the legislature and the executive. For countries that have inherited the Napoleonic model, these are outright independent judiciaries, the Cours des Comptes, which draw on legal and accounting skills, and which analyze the administration's work only to sanction formal irregularities in the management of public money.

It is evident that the parliamentary watchdogs of the Anglo-American model have been able to extend their competencies incrementally from the auditing of public expenditures to overseeing the performance of administrations. In the past three decades, these missions have been gradually complemented with evaluation of the results of programs and projects approved by the executive. Testifying to this evolution is the enlargement of the issues addressed, and the research methods used, in their inquiries by the American Government Accountability Office (GAO) and the British National Audit Office (NAO).

To monitor the actions of their governments, the parliaments of continental Europe can only rely on the traditional devices: conditioning the extent of delegated legislation with primary legislation; scrutinizing the national budget and appropriations bills; using their investigative powers; deploying the mainly legal skills of their staffs. With these limited institutional and professional resources available, incremental extension of parliamentary oversight to evaluation of the results of the executive's policies, programs and projects is very difficult.

This reconstruction shows why some countries, such as France and, most recently, Italy, have decided to resolve the impasse by resorting to the strongest of legitimations: inclusion in their constitutions of public policy evaluation as a function of parliament. ${ }^{6}$

\footnotetext{
${ }^{6}$ Also Morocco with the constitutional reform of 2011 has followed this route. Article 70 of the new Moroccan Constitution states: 'Parliament exercises legislative power. It votes laws, controls Government action and evaluates public policies.'
} 
Before this choice is analyzed more closely, a clarification is necessary. All the parliaments discussed in this paper have a system of committees based on the various areas of public intervention: education, health, national security, and so on. All of these committees, therefore, are organized by policy sectors, if we give to this term the generic meaning of a field of activity (Hogwood and Gunn 1984). As has been apparent at various points of this paper, and as the experiences of the French and Italian parliaments demonstrate, this system is not a sufficient condition for the growth of policy analytical capacity in those institutions. The constitutionalization of parliament's competencies in regard to the evaluation of public policies is justified precisely on the basis of this evidence. In the intentions of those who propose it, the effect of this strong legitimation of ex post policy evaluation should induce a recognition of the added value of a policy perspective even in the early stages of ordinary legislative procedures, steering them toward a logic of ex ante policy evaluation and design.

\section{The constitutional reforms in France and Italy}

Following the constitutional reform of 2008, Article 24 of the French Constitution states: 'Le Parlement vote la loi. Il contrôle l'action du Gouvernement. Il évalue les politiques publiques. (...). ${ }^{7}$ The text, however, does not provide for the creation of a specific parliamentary watchdog responsible for technical conduct of the evaluation. In fact, according to Article 47-2, that competency remains with the Cour des Comptes: 'The National Cour des Comptes assists Parliament in control of the action of the government. It assists Parliament and the government in the control and execution of finance laws and the social security financing laws, as well as in the evaluation of public policies. It helps to inform citizens by publishing public reports.'

Following the reform, established within the National Assembly was the Comite d'évaluation et de contrôle des politiques publiques (CEC). Its competencies, after the opinion expressed by the Constitutional Council on the Rules of the National Assembly (2009), ${ }^{8}$ are rather limited. In fact, on the basis of the opinion cited,

The monitoring and control of the execution of budget laws and the legislation regarding social security financing are excluded from the committee's jurisdiction, as well as the evaluation of any matter relating to public finance and to the financing of social security (...). Moreover, the separation of powers precludes that, in conducting the evaluations, the rapporteurs of the Committee can benefit from the assistance of experts working under the responsibility of the Government (...) The Committee's recommendations forwarded to the Government and the follow-up report on their implementation cannot, under any circumstances, issue an injunction on the Government.

The Comité has been in effective operation for too short a time for it to be possible to take stock of its impact on the parliamentarization of the policy paradigm.

Evaluation of programs in which financial and regulatory aspects predominate is usually assigned to the Cour des Comptes. Analyses of economic, social or environmental policies

\footnotetext{
7 The official English translation of this text is: 'Parliament shall pass statutes. It shall monitor the action of the Government. It shall assess public policies.'http://www2.assemblee-nationale.fr/langues/welcome-tothe-english-website-of-the-french-national-assembly\#Title5.

8 http://www.assemblee-nationale.fr/connaissance/reglement_2015_01.pdf.
} 
are conducted directly by the Comite using the standard tools of commissions of inquiry: hearings, visits to places and institutions, panels of experts. The reports tend more to emphasize the multiplicity of sources and the completeness of the information than to provide succinct and incisive recommendations. The limits imposed by the Conseil Constitutionnel explain the absence of specific follow-up reports on the effects of evaluations of the executive's and the administration's actions like those produced by the GAO and the NAO. In fact, the conclusions of the Comite cannot result in any direct conditioning on the administration, which confirms the weak powers of the French Parliament.

As regards the Italian constitutional reform, the preparatory phase and the final formulation demonstrate a marked disorientation in identifying a significant institutional placement for the evaluation of public policies.

In the spring of 2013, at a time of great political tension, the President of the Republic Giorgio Napolitano instructed two groups of experts to draw up proposals for economic and institutional reforms. ${ }^{9}$ Their document called for a commitment to 'the conduct of effective policy evaluation' in both the executive and the legislature. But the concrete references were limited to the rules of legislative drafting and to the 'Better Regulation' principles promoted by the OECD. In the autumn of 2013, a subsequent expert commission, this one appointed by the government, made a number of important proposals for constitutional reform. They included a decrease in the powers of the regions, and the end of the so-called 'perfect bicameralism,' with a reduction in the role of the Senate in ordinary legislation and the indirect election of senators by the members of the regional legislatures. The text stated that 'among the tasks of the two Houses of Parliament, and in particular the Senate, of especial importance should be "evaluation of public policies." which constitutes a specification of the function of parliamentary control., 10

These proposals were translated into a Constitutional reform bill presented to Parliament and approved on April 12, 2016, in a climate of strong conflict between majority and opposition.

The new wording of Article 55 assigned to the Senate the representation of the local institutions and established that 'it shall evaluate the public policies and the activities of public administrations, and assesses the territorial impact of EU policies.' The decision to assign policy evaluation to the upper house, moreover in a context of weakening its lawmaking function, was unique among bicameral parliaments. In addition, the new text contained no reference to the technical structure that will have the task of performing the evaluative analyses. In this regard, it should be borne in mind that almost all the technical staff serving the Italian Parliament has legal training, mitigated only recently by the inclusion of some economic, financial, and statistical specialists.

The new text was submitted to a public referendum. Also the campaign for the vote was marked by conflict between those for and against. The issue of the new functions of the Senate in the evaluation of public policies remained entirely marginal, even in the declarations of the numerous political scientists who participated in the campaign. On December 4, 2016, voters rejected the constitutional reform by a wide margin $(59 \%$ against).

The French and the Italian episodes, although their outcomes were different, share the same premise. In both cases, the power of the respective parliaments to evaluate public

\footnotetext{
${ }^{9}$ V. http://presidenti.quirinale.it/Napolitano/attivita/consultazioni/c_20mar2013/gruppi_lavoro/2013-0412_agenda_possibile.pdf.

${ }^{10}$ Commissione per le riforme costituzionali, Per una democrazia migliore, Presidenza del Consiglio dei Ministri, Roma, p. 46.
} 
policies is not considered a simple evolution of their general function of controlling the executive; rather, it requires specific constitutional legitimacy, in that it is judged more intrusive than the 'normal' commissions of inquiry conducted according to a judicial logic, and it is therefore potentially able to alter the relationship with the executive power.

\section{Conclusions}

The foregoing overview has given an idea of the difficulties encountered by attempts to enlarge the categories with which a country's institutional actors define and legitimize what they do. Generally, we expect to find obstacles and resistances in the countries that rank lowest in classifications of democratic stability. But the complications also concern countries with mature constitutional systems and with open and competitive political arenas.

These cases are generally considered to be mere technical delays due to a lack of updated skills. This judgment, which underestimates the magnitude of the discrepancy, in a certain respect pleases both the evaluators and the evaluated. There is a growing industry of governance quality assessment by international organizations, national professional societies, consulting firms, and universities. This industry has a strong interest in promoting as universally recognized and endorsed a set of standards and indicators with which to measure the value of government decisions. It is entirely in the interest of the governments subject to evaluation to align themselves formally with these criteria and to have their actual compliance overestimated, even when a bottom-up verification contradicts such alignment (Jacob et al. 2015). The win-win outcome of this game between evaluator and evaluated requires that the dissimilar logics be regarded as mere anomalies, as temporary deficiencies easy to remedy, perhaps by increasing the number of experts and consultants. The paper has argued that the problem in these countries may be not 'just' a lack of capacities, but rather a different repertoire of the ontologies used to frame the public sphere.

The policy 'ontology' is one of the building blocks of good governance. But there are European countries where this recognition is only formal, devoid of any concrete effect, because the skills and procedures used to run the institutions draw on other ideas and ideals of how to govern the res publica. The concept of governmentality, at least in the version used here, allows this diversity to be given its due importance by reconstructing the epistemic, organizational and normative aspects which legitimize it.

This perspective makes it possible to grasp the obstacles that arise when a new paradigm, that of policy, seeks a place among instruments of government with strong institutional rootedness and with (allegedly) finite sets of unambiguous instructions: the law, public finance, public administration. ${ }^{11}$

Apparently, the parliamentarization of policy evaluation in France and the attempt in Italy indicate a convergence with governmentalities that for decades have assigned to legislatures the function of verifying the problem-solving capacity of executives.

In fact, in the two countries the linkage between law, public finance, and public administration continues to predominate, as evidenced by the role of institutions emblematic of Napoleonic governmentality, such the Cours des Comptes. But law and

11 Lest this observation be interpreted as nostalgia or prejudice, I would point out that I have spent my entire professional life in an attempt to import the PAV into Italy. 
public finance also determine the parameters for verification of compliance with the constraints imposed by membership of the European Union and the EU's Monetary Union.

The difficult and incomplete processes for policy parliamentarization in France and Italy shift the attention to another variable: the internal, autonomous capacity of the policy paradigm to be convincing and to assert itself as an instrument that is a more candid, sensible, straightforward, commonsensical and, eventually, democratic way of representing and judging what governments do, taking as its parameter the concrete problems of people. This vision, in which reappears the utopian reference to the happiness of people present in the meaning of the term 'policy' in eighteenth-century Europe, in certain respects reemerges in the thought of Dewey and Lasswell. And a striving for a democracy that is more pragmatic, and therefore more realistic and efficacious also appears in the authors that in the 1950s and 1970s made the greatest contribution to the spread of this new type of useful knowledge by tying 'the art and craft' of policy analysis to Speaking Truth to Power (Wildavsky 1979) and The Intelligence of Democracy (Lindblom 1965). This endeavor is an important part of the fascinating appeal of this paradigm even outside the American cultural context that generated it.

Today, in the prescriptions that derive from the most authoritative supranational bodies, the metaphor often associated with the need to update misaligned governmentalities is that of medicine-bitter but necessary. The term 'reform' has become synonymous with interventions that the citizens, voters, and taxpayers of a country would not choose on their own, at least in the time and manner required from outside.

When greater policy capacity is required within these coordinates, conflict with the principles upon which the political democratic consensus rests may become inevitable. Hence, the emergence of the policy-oriented, or output (Peters 2011), or problem-solving (Briggs 2008) governmentality is a very complex process, open to a wide range of different effects. And it does not guarantee that a stronger policy capacity will be 'directed towards providing the knowledge needed to improve the practice of democracy.' (Lasswell 1951: 15).

Open Access This article is distributed under the terms of the Creative Commons Attribution 4.0 International License (http://creativecommons.org/licenses/by/4.0/), which permits unrestricted use, distribution, and reproduction in any medium, provided you give appropriate credit to the original author(s) and the source, provide a link to the Creative Commons license, and indicate if changes were made.

\section{References}

Abbott, A. (1988). The system of professions: An essay on the division of expert labor. Chicago: The University of Chicago Press.

Anderson, J. E. (1975). Public policy-making. New York: Praeger.

Banfield, E. C. (1977). Policy science as metaphysical madness. In R. Goldwin (Ed.), Statesmanship and bureaucracy (pp. 1-35). Washington: American Enterprise Institute.

Bevir, M. (2010). Rethinking governmentality: Towards genealogies of governance. European Journal of Social Theory, 13(4), 423-441.

Bickman, L. (Ed.). (1987). Using program theory in evaluation. New directions for program evaluation. San Francisco: Jossey-Bass.

Blum, S., \& Schubert, K. (Eds.). (2013). Policy analysis in Germany. Bristol: The Policy Press.

Bobbio, N. (1987). La scienza politica e la tradizione di studi politici in Italia. In L. Graziano (Ed.), La scienza politica in Italia. Bilancio e prospettive (pp. 44-60). Milano: Angeli.

Bovens, M. (1998). The quest for responsibility. Accountability and citizenship in complex organisations. Cambridge: Cambridge University Press. 
Briggs, X. (2008). Democracy as problem solving: Civic capacity in communities across the globe. Cambridge: MIT Press.

Burchell, G., Gordon, C., \& Miller, P. (Eds.). (1991). The Foucault effect: Studies in governmentality. Chicago: University of Chicago Press.

Peuter De, B., \& Pattyn, V. (2009). Evaluation capacity: Enabler or exponent of evaluation culture. In A. Fouquet \& L. Méasson (Eds.), L'évaluation des politiques publiques en Europe: Cultures et futures (pp. 133-142). Paris: L'Harmattan.

Dean, M. (1994). Critical and effective histories. Foucault's methods and historical sociology. London: Routledge.

Dye, T. R. (1972). Understanding public policy. Englewood Cliffs, NJ: Prentice-Hall.

Dyson, K. H. F. (1980). The state tradition in Western Europe: A study of an idea and institution. New York: Oxford University Press.

Ellul, J. (1965). Propaganda: The formation of men's attitudes. New York: Knopf.

Foucault, M. (1977-1978). Sécurité, territoire, population: cours au College de France. Ed. Fr: (2004). Paris: Gallimard-Seuil. Ed. En: (2007). Security, territory, population: lectures at the College de France 1977-1978. New York: Palgrave Macmillan.

Kellogg Foundation. (2004). Logic model development guide: Using logic models to bring together planning, evaluation, and action. Battle Creek, MI: W.K. Kellogg Foundation.

Giraud, O., \& Warin, P. (2008). Politiques publiques et démocratie. Paris: La Découverte/Pacte.

Goldwin, R. A. (Ed.). (1980). Bureaucrats, policy analysts, statesmen: Who leads?. Washington, DC: AEI Press.

Gruber, T. (1993). A translation approach to portable ontology specifications. Knowledge Acquisition, 5(1), 199-220.

Heidenheimer, A. J. (1986). Politics, policy and policey as concepts in English and continental languages: An attempt to explain divergences. The Review of Politics, 48(1), 3-30.

Hogwood, B. W. (1984). Policy analysis: The dangers of over sophistication. Public Administration Bulletin, 44, 19-28.

Hogwood, B. W., \& Gunn, L. A. (1984). Policy analysis for the real world. Oxford: Oxford University Press.

Howlett, M. (2009). Policy analytical capacity and evidence-based policy-making: Lessons from Canada. Canadian Public Administration, 52(2), 153-175.

Jacob, S., Speer, S., \& Furubo, J. (2015). The institutionalization of evaluation matters: Updating the international atlas of evaluation 10 years later. Evaluation, 21(1), 6-31.

Jobert, B., \& Muller, P. (1987). L'Etat en action. Politiques publiques et corporatismes. Paris: Presses Universitaires de France.

Lasswell, H. D. (1951). The policy orientation. In H. D. Lasswell \& D. Lerner (Eds.), The policy sciences (pp. 3-15). Palo Alto, CA: Stanford University Press.

Lasswell, H. D., \& McDougal, M. S. (1943). Legal education and public policy: Professional training in the public interest. Yale Law Journal, 52(2), 203-295.

Lindblom, C. E. (1965). The intelligence of democracy. New York: Free Press.

Lodge, M., \& Wegrich, K. (Eds.). (2014). The problem-solving capacity of the modern state: Governance challenges and administrative capacities. Oxford: Oxford University Press.

Madison, J. (1787). The union as a safeguard against domestic faction and insurrection. Federalist No. 10. http://www.constitution.org/fed/federa10.htm. Accessed June 25, 2016.

Mény, Y., \& Thœnig, J. (1989). Politiques publiques. Paris: Presses universitaires de France.

Miller, P., \& Rose, N. (2008). Governing the present: Administering economic, social and political life. Cambridge: Polity Press.

Muller, P. (2008). Analyse des politiques publiques et sciences politique en France: Je t'aime moi non plus. Politiques et Management Public, 26(3), 51-56.

National Academy of Sciences, Committee on Science, Engineering, and Public Policy (1986). Research briefings 1986. Washington, DC: The National Academies Press. http://www.nap.edu/catalog/911/ research-briefings-1986.

Peters, B.G. (1996). The policy capacity of government. Ottawa: Canadian Centre for Management Development. http://publications.gc.ca/collections/Collection/SC94-61-18-1996E.pdf. Accessed June $25,2016$.

Peters, B. G. (2011). After managerialism what?: The return to political and strategic priorities. Croatian and Comparative Public Administration, 11(3), 605-625.

Pierre, J., \& Peters, B. G. (2005). Governing complex societies. Trajectories and scenarios. Basingstoke: Palgrave McMillan.

Regonini, G. (2012). Parlamenti analitici. Rivista Italiana di Politiche Pubbliche, 1, 33-87. 
Rose, N. (1996). Governing 'advanced' liberal democracies. In N. Rose, A. Barry, \& T. Osborne (Eds.), Foucault and political reason (pp. 305-443). London \& Chicago: UCL Press.

Rosenbloom, D. H. (1987). Constitutional perspectives on public policy evaluation. Policy Studies Journal, 16(2), 233-241.

Rosenbloom, D. H. (2000). Retrofitting the administrative state to the Constitution: Congress and the judiciary's twentieth-century progress. Public Administration Review, 60(1), 39-46.

Sartori, G. (1989). The essence of the political in Carl Schmitt. Journal of Theoretical Politics, 1(1), 63-75.

Schambra, W. (2009). Obama and the policy approach. National Affairs, 1, 127-144. http://www. nationalaffairs.com/doclib/20091229_Schambra_Fall09.pdf. Accessed June 25, 2016.

von Beyme, K. (2013). Historical forerunners of policy analysis in Germany. In S. Blum \& K. Schubert (Eds.), Policy analysis in Germany (pp. 19-27). Bristol: Policy-Press.

Webber, C., \& Wildavsky, A. (1986). A history of taxation and expenditure in the Western world. New York: Simon \& Schuster.

Weber, M. (1918). Parliament and government in a reconstructed Germany (A contribution to the political critique of officialdom and party politics). In M. Weber (Ed.), (1922-1978), Economy and society: An outline of interpretive sociology (pp. 305-443). Berkeley: University of California Press.

Wildavsky, A. (1979). Speaking truth to power: The art and craft of policy analysis. Boston: Little, Brown and Company.

Wilson, W. (1885). Congressional government: A study in American politics. Boston: Houghton-Mifflin, http://www.gutenberg.org/files/35861/35861-h/35861-h.htm. Accessed June 25, 2016.

Woo, J., Ramesh, M., \& Howlett, M. (2015). Legitimation capacity: System-level resources and political skills in public policy. Policy and Society, 34(3-4), 271-283. 